\title{
Aircraft Wet Leases: Accounting Dissonance with Competitive Strategy and Travelers' Perspectives
}

\author{
Francesco Bellandi ${ }^{1}$ \\ Correspondence: Francesco Bellandi, Flat 29, 4 New Crane Place, E1W 3TS London, United Kingdom. E-mail: \\ francesco_bellandi@yahoo.com
}

Received: July 11, 2018

doi:10.5539/ijbm.v13n11p214
Accepted: September 26, 2018

Online Published: October 12, 2018

URL: https://doi.org/10.5539/ijbm.v13n11p214

\begin{abstract}
Under IFRS 16 and Topic 842 a lessee's right to control the use an aircraft in a wet lease is an asset. On the other hand, contract analysis sees a wet lease as an opportunistic, external, temporary, competitive tool for flight flexibility and tactic cost advantage. Finally, travelers may be worried of safety and service quality or disruption in a wet lease, as the flight is not operated by their airline. This article addresses the accounting for aircraft wet leases as an exemplar case of a lease with substantial services, to discover that there is dissonance between the economic views behind accounting, business model and competitive strategy, and user service perspective.

After a thorough analysis of IFRS 16 and Topic 842 applied to wet leases for the first time in a public study, a review of disclosures in financial statements of 59 sampled airlines confirms a clear contrast between the competitive analysis, traveler's perspective and the accounting view. Such a dystonia is supposed to reflect the view of investors and creditors, which the IASB's and FASB's Conceptual Frameworks denote as primary users of financial statements, as opposed to other members of the public, including customers. This results in a failure to give enough space to the indirect effects of such alternative views on customers' demand and revenue, hence company's prospects for future net cash inflows, which according to the Conceptual Framework is the main driver of investors and creditors decision making.
\end{abstract}

\section{Highlights}

- Contract analysis is provided on wet leases as a business model competitive tool.

- $\quad$ Analysis under IFRS 16 and Topic 842 and IAS 17/IFRIC 4 and Topic 840 is provided.

- Above views are compared with travelers' concerns about safety and service quality.

- Airline financial statements disclosures on these three views are analyzed.

- Views are traced to primary versus other users' conflict in the Conceptual Framework.

Keywords: Topic 842, IFRS 16, aircraft wet lease, competitive business strategy

\section{Introduction}

Airlines make a heavy use of wet leases. This article focuses on such leases as an extreme example of a hybrid contract for the use of assets mixed with substantial services and investigates how the role of services in such leases may affect a company's competitive view, accounting view and customers' view.

In January 2016, the IASB issued the new standard IFRS 16, Leases, which is effective for annual reporting periods beginning on or after January 1, 2019. Early application is permitted, provided an entity concurrently or before applies IFRS 15, Revenue from Contracts with Customers. In February 2016, the FASB issued Accounting Standards Update No. 2016-02, Leases (Topic 842). It is effective for fiscal years beginning after December 15, 2018 and respective interim periods for public business entities, not-for-profit entities that have issued or are a conduit bond obligor for traded securities, and employee benefit plans filing with the SEC. For all other entities, such date shifts one year for annual financial statements and two years for interim reports. Limited to entities that meet the definition of a public business entity only for a requirement to include or the inclusion of their financial statements or financial information in another entity's filing with the SEC, the SEC staff announced that it would not object to adopting Topic 842 for fiscal years beginning after December 15, 2019, and interim periods within fiscal years beginning after December 15, 2020 (FASB ASC 606-10-S65-1).

This paper is organized as follows. It first reviews the business model of wet leases in the airline sector, to derive 
the economic substance of the contract from a competitive perspective. It then stress-tests the application of lease extant GAAP and the new standards IFRS 16 and Topic 842 to wet leases, to derive the economic substance that underlies the accounting model. Next, it highlights the dystonia among these views and the traveler's safety and service perception. It reviews a sample of companies' financial statements to uncover if and what companies disclose under these three perspectives. Finally, it reconciles those views to the role of financial statements different users in the IASB and FASB Conceptual Frameworks.

This paper concludes that -IFRS 16 and Topic 842 limit to the direct effects, but do not give enough space to competitive business model and service aspects of leases to represent the indirect effects to the investor's perspective, a fact which therefore appears to make them not fully fit for purpose to serve the objective informed on by the IASB and FASB Conceptual Frameworks.

\section{Literature Review}

This paper is innovative because, although there is some accounting and professional literature about the impact of services in leases, as cited in this article, there is a substantial lack of scientific literature on the subject, especially on wet leases. A few articles have addressed IFRS 16 for the airline industry (Öztürk and Serçemeli 2016); Bourjade et al. 2017); (Wei-Tung et al. 2018), but not on the subject matter of this article. Briggs at al. 2017 have addressed variable lease payments.

Accounting research on leases has been divided into five lines (Morales-Diaz et al. 2018): economic consequences of accounting standards, determinant of leases, value relevance, leases' valuation, and the impact of leases on accounting ratios. Lots of scientific articles have instead focused on the effects of IFRS 16 on financial statements and ratios and the impacts of the capitalization of the unrecorded leases, among the most recent (Gross et al. 2014); (Bohušováa 2015); (Ericson and Skarphagen 2015); (Nunung 2015); (Wong and Joshi 2015\}; (Hsieh et al. 2015); (Öztürk 2016); (Sar1 et al. 2016); (Sacarin 2017); (Arnold and Tahtah 2017); (Moralez-Diaz 2018). Among other aspects, some articles have dealt with the effect on credit risk, among the most recent (Altamuro et al. 2014); (Masaki 2017); (Lim 2017); lease term (Bohušováa et al. 2014); and macroeconomics or industry competitiveness aspects of lease (Andrikopoulos et al., 2014); (Vakhitov Damir et al. 2014).

\section{Material and Methods}

This article addresses the following research questions:

Research question No. 1: What is the business model and competitive view of wet lease contracts and how do companies disclose it?

Sub-research questions include:

- What are the main features of wet lease contracts?

- What are the implications in terms of nature of those contracts when seen from the business model and competitive view?

- How do companies disclose the use of wet leases and the business reasons for it?

Research question No. 2: What is the accounting view of wet leases and how do companies disclose it?

Sub-research questions are:

- What is the role of services in a wet lease and how do they affect the lease definition test under the extant and new lease standards?

- How does the right to control the use of the aircraft vs. the risks and rewards analysis apply to a wet lease contract under the extant and new lease standards?

- How does the structuring of operation and maintenance in the contract (including separability and payment variability) affect wet leases under the extant and new lease standards?

- What do company disclose about their accounting for wet leases?

Research question No. 3: Do the accounting view and the business model and competitive view conflict with the travelers' view?

- Is the customers' perspective reflected in the new lease standards disclosure requirement?

- Are company's disclosures transparent enough to make customers understand that an airline uses wet leases and how this may affect the customer's experience? 
- What can be concluded overall on whether the three views reconcile each other?

The research in this article proceeds from both a qualitative and a quantitative perspective.

It analyses the main features of wet leases contracts and their use by airlines. This is based on a review of typical contracts and a review of legal and contractual analyses.

It conducts a thorough accounting policy analysis of the application of the new international and U.S. lease accounting standards (IFRS 16 and Topic 842) and the previous standards (IAS 17, IFRIC 4, Topic 840) to wet lease contracts.

It reviews the financial statements of sampled airlines. The sample first considered the top 10 airlines by revenue, the top 10 airlines by passengers, and the top 10 European airlines. It then took the top 10 airlines of the survey of the World's Top 100 Airlines - 2007. Then, from the same survey it selected a random sample of at least 2 companies for each 10 rankings (e.g. at least 2 out of the companies ranking from 11 to 20 , at least 2 from 21 to 30 , etc.). To include companies ranked below 100, other companies were included, by textual search of wet and ACMI leases in Google. A limited number of lessors is also included, by textual search in Google, to compliment with indications from the lessor's perspective. Companies that do not mention wet or ACMI leases at all were not reported in the final findings. The selection of top ranking companies serves the purpose to make sure that the most prominent companies are considered. The use of the World's Top 100 Airlines - 2007 intends to select those airlines that were voted in the customer survey, to consider customers' perception. The inclusion of other companies is to balance the sample through random representation of the remaining population.

Top 10 airlines by revenue (American Airlines, Delta Air Lines, United Continental, Lufthansa, Air France-KLM, International Airlines Group, Southwest Airlines, China Southern Airlines, China Eastern Airlines, All Nippon Airways)

Additional top 10 airlines by passengers not included above (Ryanair, EasyJet, Turkish Airlines)

Additional top 10 largest European airlines not included above (Aeroflot, Norwegian Air Shuttle, SAS, Wizz Air)

Additional top 10 airlines in World's Top 100 Airlines - 2007 survey not included above (Qatar Airways, Singapore 8

Airlines, Emirates, Cathay Pacific, EVA Air, Etihad Airways, Hainan Airlines, Garuda Indonesia)

Additional random sample out of next 90 airlines in World's Top 100 Airlines - 2007 survey - see above for

methodology (Aegean Airlines, Aeroméxico, Air Asia, Air Berlin, Air Canada, Air China, Air Lingus, Air Malta,

Alitalia, American Eagle, British Airways, Finnair, Jet Airways India, Oman Air, Qantas, Royal Air Maroc, Virgin

Australia, Vueling, West Jet)

Additional random sample of companies not ranked top 100 above (Air Arabia, Air India, Air Lease, Alliance Aviation

Services, Atlas Air World Wide Holdings, Cargojet, Comair, El Al Israel Airlines, Flybe Group, Iberia, Meridiana Fly,

Shandong Airlines, Spirit Airlines, Sprint Airlines, TNT)

Total gross sample

Less sampled companies that did not report wet leases (Aeroflot, Air Asia, Air France, Air Lease, Air Malta, All

Nippon Airways, American Eagle, British Airways, Comair, China Eastern, China Southern, Delta, Emirates, Etihad

Airways, Eva Air, Garuda Indonesia, Hainan Airlines, Iberia, Qatar Airways, Royal Air Maroc, Ryanair, Singapore

Airlines, Southwest Airlines, Spirit Airlines, Vueling, Wizz Air)

Total net sample

3

10

3

8

$-26$

The analysis went through the most recent financial statements that were available for download in the Internet. The study has involved both a textual search within the financial statements and an extensive reading of the accounts, the lease disclosures and management commentary related to leases. As the sampled companies are from different jurisdictions, the GAAP applied are mainly IFRS and U.S. GAAP (including extant lease IFRS and U.S. GAAP lease standards, as IFRS 16 and Topic 842 are not effective yet), as well as some local GAAP, depending on the specific company.

\section{Research Question No. 1: Business Model View}

\subsection{Main Features of Wet Lease Contracts}

Wet and dry leases are specific types of aircraft leases, with a few possible adaptations depending on the circumstances. The contractual aspects of these agreements of course have peculiarities depending on the jurisdiction with specific legal context, regulations and restrictions (EC Regulation No. 1008/2008); (EC Regulation No. 859/2008); (Geneva Convention, 1948); (UK SI 2009 No. 41); (Cini Chacko, 2011); (La Spina, 2011); (Hengen, 2007). 
In a wet lease, the lessor operates the aircraft under its Air Operator's Certificate (AOC), and provides crew. The lessor commits to operate certain flights during a certain period, normally for a short term, in the UK up to a maximum of 14 months. The lessee provides the flight number and is the contractual party to passengers. The lessee generally pays by the number of hours operated, with a minimum of guaranteed block hours per month. It is generally in charge of the cost of flight/navigation for air-traffic control services, fuel, landing/handling/parking/storage fees, crew hotel accommodation including meals, transportation and visa fees, import duties and local taxes, passenger/luggage and cargo insurance. An ACMI (Aircraft, Crew, Maintenance, Insurance) lease is a form of, or sometimes an alternative name for wet lease, where the lessor provides the aircraft, complete crew, maintenance and insurance. A damp lease is a wet lease with a partial crew, generally a cockpit crew but not cabin attendants. A moist lease is a wet lease without a crew.

Conversely, in a dry lease the lessee operates an aircraft under its Air Operator's Certificate (AOC). The lease covers only the basic aircraft. It is generally for longer term leases (from two years onwards) and has no purchase option.

\subsection{Nature of Wet Lease Contracts When Seen from the Business Model and Competitive View}

Airlines often lease aircraft from a leasing company or another airline. Although the economic reasons of leases are common to all companies in all industries, there are specific business reasons for why an airline may want to use a wet lease.

As Table 1 summarizes, airlines can temporarily increase capacity through wet leases. The benefits to the lessee include an increase in service capacity with no additional fleet and crew, often for temporary use, a modular approach to starting new routes or serving new segments, lowering costs, or pre-empting competitors' access to certain routes.

Some of the benefits to the lessor comprise guaranteeing an additional business for a certain period and indirectly expanding to non-served markets without sustaining the related marketing costs.

A recent notable example is Air Berlin, which secured a 6-year agreement to wet lease with Lufthansa to provide aircraft with cockpit and cabin crew, maintenance, insurance and overhead services to Eurowings and Austrian Airlines. The deal is said to have the goal to focus on higher yield markets as well as to keep EasyJet and Ryanair out of Germany as much as possible (Air Berlin, 2016).

Table 1. Basic features of wet leases

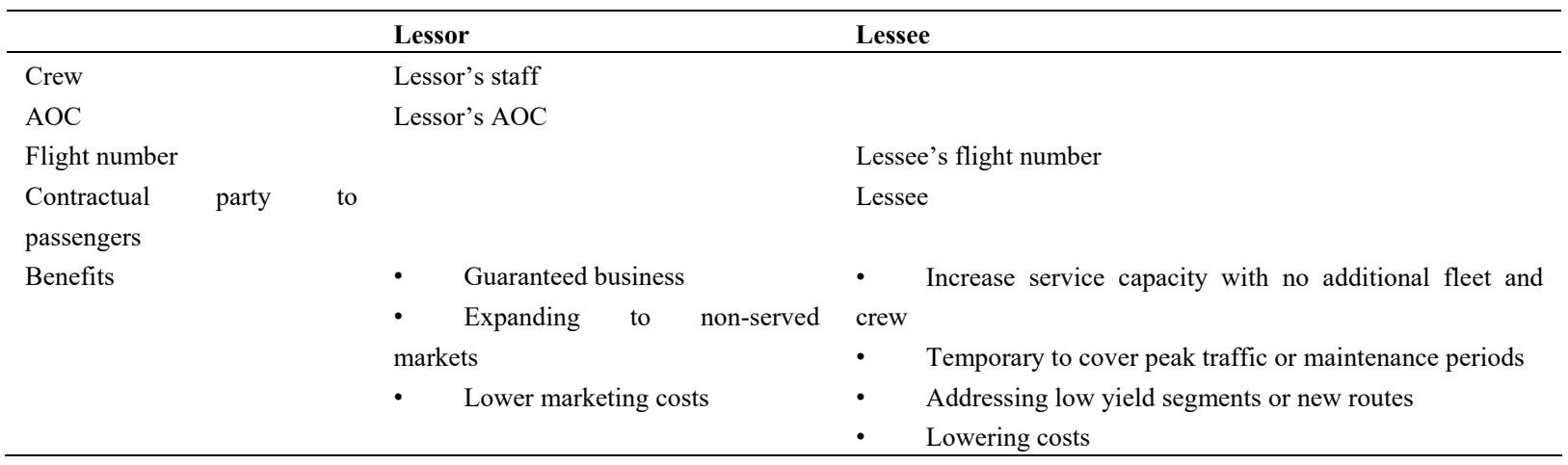

As the previous discussion shows, as opposed to a permanent asset of the company, from a business model perspective this instrument as a typically opportunistic, flexible and competitive tool, as a temporary way of entering, changing, exiting or competing in some routes. It permits fast action or reaction by leveraging assets of others and bundling of assets and services. This is in clear contract with the accounting view where the right to use is the customer's (lessee's) asset (see explanation in Section 4 below).

\subsection{Companies Disclosure of the Use and Business Reasons of Wet Leases}

The sampled companies give limited information of wet, ACMI, damp and dry leases. Such information is generally furnished as part of management commentary, which is not subject to IFRS or generally entire GAAP requirements and only subject to limited-scope audit.

The sampled companies mention such types of leases, and some companies briefly explain business reasons, such as "short-term" "to cover the needs of charter operation" (Aegean), "to redeploy aircraft during lean season" 
(Air Asia), to add flexibility into the schedule and to build peak season resilience (Easyjet), or as a "sale of capacity during the low season" (Meridiana). Company only occasionally mention number or types of aircraft on wet leases (e.g., Cathay Pacific, Jet Airways India, Lufthansa, Meridiana, Norwegian, SAS). These characterizations, albeit limited, confirm the use of such leases as a temporary, agile, competitive tool in the airline business model.

\section{Research Question No. 2: Accounting View}

\subsection{Role of Services in a Wet Lease and Lease Definition Test}

There have been different views on how to recognize a wet lease, mainly because a wet lease includes some service components, such as a crew, maintenance, or insurance. Maintenance is generally an important element in aircraft leases, as it is itself part of the definition of a wet lease or ACMI (i.e., "maintenance" is part of the acronym). In addition, maintenance is an important activity for aircraft. A similar consideration holds for operating services of aircraft.

The point of whether services affect lease definition has been debated, for example the EFRAG reports some views that an obligation to operate and maintain the asset throughout the contract would be a significant continuing involvement of the lessor that would indicate the substance of the agreement as a service (EFRAG, 2013, para. 25), (EFRAG, 2014, para. 16).

The main point for a lessee is whether the agreement meets the definition of a contract that is, or contains, a lease, or is a service contract. In the former case, under extant GAAP, the lessee would determine whether it should be classified as a finance (i.e., capital, under U.S. GAAP) lease or an operating lease. Under IFRS 16, this step does not exist anymore for a lessee. Similarly, the lessor may wonder whether the agreement is a service or a lease, in which case (also under the new standards) it must determine its classification.

Under current guidance, contrary to services, a lease conveys the right to use an asset (under Topic 840, property, plant, or equipment only) for a period of time in exchange for consideration, and depends on an identified asset (IASB, 2014, IAS 17, para. 4), (IFRS Interpretations Committee, 2009, IFRIC 4, paras. BC24, BC37), (IASB, 2016, IFRS 16, para. 9), (FASB, 2018, FASB ASC 840-10-15-5; 840-10-15-10; 840-10-55-26). IASB (2016) IFRS 16 and FASB (2016) ASU 2016-02 reinforce and articulate such differences between a lease and a service contract (IASB, 2016, IFRS 16, paras. BC32-BC34, BC105, BC125), (FASB, 2016, ASU 2016-02, paras. BC40-BC42). Table 2 illustrates.

Table 2. The difference between a lease and a service contract

\begin{tabular}{|c|c|c|}
\hline & Lease & Service Contract \\
\hline Which party controls the use of the asset & $\begin{array}{l}\text { Customer controls the use of an identified } \\
\text { asset }\end{array}$ & $\begin{array}{l}\text { Supplier controls the use of any assets used } \\
\text { to deliver the service }\end{array}$ \\
\hline What the customer obtains & $\begin{array}{l}\text { The use of the asset since the } \\
\text { commencement of contract }\end{array}$ & The service as it is performed \\
\hline Unconditional obligation to pay & For that right of use the asset & For the services provided to date \\
\hline Fulfilment & $\begin{array}{l}\text { Requires making the asset available for use } \\
\text { by the customer throughout the contractual } \\
\text { term }\end{array}$ & May or may not require the use of an asset \\
\hline Focus & There must be focus on the asset & $\begin{array}{l}\text { Focus on the service. There need not be an } \\
\text { asset }\end{array}$ \\
\hline
\end{tabular}

IASB (2016) IFRS 16, para. IN2, Example 10 illustrates the different characterization of an agreement as a lease or service contract. This depends on whether the supplier (in the case of a service contract) or the customer (in the case of a lease) is the only party that can make relevant decisions about the use of the asset (in the example, delivery and installation of the asset, decisions about its use, integration within the customer's operations). In a service contract, unlike in a lease, the customer determines the level of service required, without controlling the use of the asset.

IASB (2016) IFRS 16, Effect Analysis, pp. 11, 33 concludes that IFRS 16 will likely separate some service contracts historically subsumed into leases. The issue is relevant, because the new standards bring back previously classified operating leases on balance-sheet. On the other hand, the practical expedient not to separate non-lease components from lease components would translate into capitalizing services with leases, thus 
overstating assets and liabilities (IASB, 2016, IFRS 15, para. 15), (FASB, 2018, FASB ASC 842-10-15-37), (FASB, 2016, ASU 2016-02, para. BC149). However, the IASB expects lessees not to adopt this practical expedient for leases with substantial services, as this would boost their lease liabilities (IASB, 2016, IFRS 16, para. BC135), (FASB, 2016, ASU 2016-02, para. BC150).

IAS 17 and Topic 840 specify that the fact that a contract contains substantial services by the lessor to operate or maintain the asset does not affect the classification as a lease if the agreement transfers the right to use the asset (IASB, 2014, IAS 17, para. 3), (FASB, 2018, FASB ASC 840-10-15-8). IFRS 16 and ASU 2016-02 confirm such a conclusion, so the presence of substantial services does not per se disqualify the contract as a lease (IASB, 2016, IFRS 16, para. BC125), (FASB, 2016, ASU 2016-02, para. BC142). The standards provide some examples (FASB, 2018, FASB ASC 842-10-55-71). This gives an answer to the debate (see research question No. 3) that a service that is the predominant feature of the agreement would call for characterization of the whole agreement as a service contract. The pronouncements place this consideration at lease definition level, a fact that does not impede to consider services as a non-lease component, if the separability test concludes so.

\subsection{Right to Control the Use of Asset vs. the Risks and Rewards Analysis}

The new lease standards IFRS 16 and Topic 842 move to a notion of control. This is relevant to the analysis of aircraft wet leases. As mentioned in the discussion of research question No. 3, some have claimed service contract classification on the basis that the supplier maintains operating risks and the risk of availability of the asset. In addition, as the agreement is usually for a portion of the aircraft life, a wet lease may leave capital risk to the lessor, even where the control criterion is met. Another issue in the risk analysis is who bears the cost and risk of maintenance, which much depends on how the contract is structured. It is then important to understand the interaction of the control approach and risks and rewards in the current and new standards.

Both IAS 17 and Topic 840 define leases in terms of conveyance of the right to use an asset (IASB, 2014, IAS 17, para. 4), (FASB, 2018, FASB ASC 840-10-20). At the level of lease definition, EITF 01-8 (Subtopic 840-10) and IFRIC 4 had already introduced the notion of control, without negating the risks and rewards approach, which applies later at the level of lease classification for both lessees and lessors under extant GAAP, but for lessors only under the new standards. Under current GAAP, only once an entity has concluded that an agreement is, or contains, a lease, it applies the risks and rewards approach to classify it (IFRS Interpretations Committee, 2009, IFRIC 4, paras. BC6, BC34(d), BC36(c)). In fact, the transfer of substantially all the risks and rewards of ownership of an asset to the lessee discriminates a finance lease from an operating one for both the lessee and the lessor (IASB, 2014, IAS 17, paras. 4, 7-8). The same principle inspires the lease classification test in Topic 840 (FASB, 2018, FASB ASC 840-10-25-1, 840-10-10-1). Conversely, the risks and rewards approach remains in IFRS 16 only from the lessor classification viewpoint.

According to extant GAAP, the right to control the use of the underlying asset represents the conveyance of the right to use the asset (IFRS Interpretations Committee, 2009, IFRIC 4, para. 9), (FASB, 2018, FASB ASC 840-10-15-6). The conveyance of certain risks and rewards incident to ownership is not conclusive that the agreement conveys the right to use the asset (FASB, 2003, EITF 01-8, para. B14), but the reverse generally holds true.

In the new standards, the control element more consistently aligns the definition of a lease with the control principle in the revenue standards IFRS 15 and Topic 606 (IASB, 2016, IFRS 16, para. BC107), (FASB, 2016, ASU 2016-02, para. BC92). IFRS 16 and ASU 2016-02 define a lease as a contract that conveys the right to control the use of an identified asset for a period of time in exchange for consideration (IASB, 2016, IFRS 16, paras. 9, Appendix A), (FASB, 2018, FASB ASC 842-10-15-1), no longer simply the right to use. In addition, the right to control the use of the asset includes both the right to obtain substantially all the economic benefits from its use, which is an element in the rewards approach, and the right to direct its use. The latter aligns it to the concept of control applied in consolidation in IFRS 10 and Topic 810 (IASB, 2016, IFRS 16, paras. BC106, BC117), (FASB, 2016, ASU 2016-02, paras. BC8, BC124, BC134).

In terms of defining what risks and rewards are, IAS 17 (as IFRS 16) spells out possible risks incident to ownership, such as losses from idle capacity, technological obsolescence, variations in returns, and rewards of ownership, e.g., profitability over the asset's economic life, appreciation in value or gain from disposal of residual value (IASB, 2014, IAS 17, para. 7), (IASB, 2016, IFRS 16, para. B53). However, even under a risks and rewards approach, the risk profile of a finance lease does not equate that of ownership, as IFRS 16 and ASU 2016-02 note. For example, one of the reasons for leasing is to reduce the risks that would otherwise be incident to ownership (IASB, 2016, IFRS 16, para. IN4). Also, a right-of-use asset for a lessor may not embed residual asset risk compared to an owned asset or may bear the risk of replacement at a lower rate (IASB, 2016, IFRS 16, 
para. B207), (FASB, 2016, ASU 2016-02, para. BC262).

The focus then becomes how to qualify the right to control the use of the asset and what the implications on wet leases are. This analysis of course assumes that there is an identified asset (in this case, an aircraft). Table 3 applies the criteria in extant GAAP to define whether an agreement is or contains a lease to aircraft wet leases. Table 4 makes the same based on IFRS 16 and ASU 2016-02.

Table 3. When the agreement conveys the right to (control the) use the asset under extant GAAP

\begin{tabular}{|c|c|c|c|}
\hline $\begin{array}{l}\text { Any one of } \\
\text { following } \\
\text { criteria }\end{array}$ & $\begin{array}{l}\text { IFRS Interpretations Committee (2009), IFRIC 4, } \\
\text { para. } 9 \text { and FASB (2006) FASB ASC 840-10-15-6 }\end{array}$ & $\begin{array}{l}\text { IFRS } \\
\text { Committee }(2009), \text { IFRIC 4, } \\
\text { paras. BC30-BC31, BC34, } \\
\text { BC36 and / FASB (2006) } \\
\text { FASB ASC } 840-10-15-6 \\
\text { Examples }\end{array}$ & $\begin{array}{l}\text { Application to Wet } \\
\text { Leases }\end{array}$ \\
\hline \multirow[t]{3}{*}{$\begin{array}{l}\text { Criterion } \\
\text { physically } \\
\text { control the us } \\
\text { through } \\
\text { operations }\end{array}$} & \multirow[t]{3}{*}{$\begin{array}{l}\text { Purchaser has the ability or right to operate the asset or to } \\
\text { direct others to do so, plus it obtains or controls more } \\
\text { than an insignificant amount (ASC 840-10-15-6 states } \\
\text { more than a minor amount) of output or other utility }\end{array}$} & $\begin{array}{l}\text { Ability to hire, fire or replace } \\
\text { the operator }\end{array}$ & $\begin{array}{l}\text { Not met. However, the } \\
\text { IFRIC does not regard } \\
\text { this criterion alone as } \\
\text { determinative }\end{array}$ \\
\hline & & $\begin{array}{l}\text { Ability to operate the asset or to } \\
\text { direct others to do so }\end{array}$ & $\begin{array}{l}\text { Purchaser has no ability } \\
\text { to operate but can direct } \\
\text { others to operate the } \\
\text { asset }\end{array}$ \\
\hline & & $\begin{array}{l}\text { Exclusive ability to specify } \\
\text { significant operating policies } \\
\text { and procedures in the } \\
\text { arrangement }\end{array}$ & $\begin{array}{l}\text { Whether purchaser has } \\
\text { such an ability and } \\
\text { supplier cannot change } \\
\text { policies depends on the } \\
\text { agreement }\end{array}$ \\
\hline $\begin{array}{l}\text { Criterion 2: } \\
\text { physically } \\
\text { control the use } \\
\text { through access }\end{array}$ & $\begin{array}{l}\text { Purchaser has the ability or right to control physical } \\
\text { access, plus it obtains or controls more than an } \\
\text { insignificant amount (ASC } 840-10-15-6 \text { states more than } \\
\text { a minor amount) of output or other utility }\end{array}$ & - & Generally met \\
\hline \multirow[t]{4}{*}{$\begin{array}{l}\text { Criterion 3: } \\
\text { output and price }\end{array}$} & \multirow{4}{*}{$\begin{array}{l}\text { It is remote that a party other than the purchaser takes } \\
\text { more than an insignificant amount (ASC 840-10-15-6 } \\
\text { states more than a minor amount) of asset's output or } \\
\text { other utility, and price for the asset's output is neither } \\
\text { contractually fixed per unit of output nor equal to the } \\
\text { current market price per unit of output as of the time of } \\
\text { delivery of the output }\end{array}$} & $\begin{array}{l}\text {-Purchaser takes } \\
\text { substantially all of the output } \\
\text { from an asset during the } \\
\text { contract term }\end{array}$ & Generally met \\
\hline & & $\begin{array}{l}\text { The related service contract } \\
\text { does not operate independently }\end{array}$ & $\begin{array}{l}\text { Met: generally, the } \\
\text { lessee cannot terminate } \\
\text { the service element } \\
\text { alone }\end{array}$ \\
\hline & & $\begin{array}{l}\text { Purchaser's entitlement to } \\
\text { damages in the event of default } \\
\text { by the supplier indicates that a } \\
\text { right of use was originally } \\
\text { conveyed }\end{array}$ & Generally met \\
\hline & & $\begin{array}{l}\text { Fixed capacity charge designed } \\
\text { to recover the supplier's capital } \\
\text { investment in the } \\
\text { underlying asset }\end{array}$ & $\begin{array}{l}\text { E.g., price per hour } \\
\text { operated }\end{array}$ \\
\hline
\end{tabular}


Table 4. When the agreement conveys the right to control the use the asset under the new standards

\begin{tabular}{ll}
\hline IASB (2016) IFRS 16, paras. B9, B21, B24 & IASB (2016) IFRS 16, paras. B14, B18, B22, \\
and FASB (2016) FASB ASC 842-10-15-4, & B25-B29, IE2 Example 7, BC22, BC114, \\
20 & BC120; FASB (2016) FASB ASC 842-10-10, \\
& 14, 15-18, 24, 25, 26; FASB (2016) ASU \\
& 2016-02, paras. BC131, BC137 Examples \\
\hline
\end{tabular}

Both conditions to be met:

Criterion 1: Right to obtain substantially all of

the economic benefits from its use throughout

the period of use
Supplier's non-substantive substitution rights do not negate the classification as a lease
Application to Wet Leases

Generally met: exclusive use of the aircraft throughout the period of use

Generally met: e.g., substitution for maintenance or repair where the purchaser, not the supplier, would benefit economically from the exercise

Consider the economic benefits within the defined scope of a customer's right to use the asset

Contractual and legal restrictions in the contract, such as up to a certain number of miles or a specific territory, may only define the scope of customer's right to use

Criterion 2: Purchaser has the right to direct

Determining or being able to change type of, when, where, whether and quantity of output

through:

-a right to direct how and for what purpose the asset is used (consider the decision-making rights that are most relevant as affecting the economic benefits to be derived from use), or -if decisions on how and for what purpose are predetermined, purchaser has exclusive right to (direct others to) operate it, or purchaser designed the asset so to predetermine how and for what purpose
Operating or maintaining rights that are not right to direct how and for what purpose do not negate the classification as a lease

Predetermined by the design of the asset, or predetermined by contractual restrictions on the use of the asset
Generally met: e.g., deciding routes, timetable, passenger class types, whether and how much to fly Generally met: e.g.: supplier is responsible for operating the aircraft but does not decide its use e.g., the type of aircraft predetermines the length of flight but within those technical constraints purchaser decides how and for purpose to operate

Under current guidance, the right to control the use of an asset may derive from obtaining substantially all the output from the asset during the contract term in conjunction with certain types of pricing (criterion No. 3 under IFRIC 4 and ASC 840-10-15-6). The new standards in a way rephrases this as obtaining substantially all of the economic benefits from its use through the period of use but adds that there must also be the power to direct the use of the asset (IASB, 2016, IFRS 16, para. BC117), (FASB, 2016, ASU 2016-02, para. BC134).

Power to direct the use is not the same as the power to direct others to operate the asset in the current criterion No. 1. While criterion No. 1 refers to physically control the use through operations, the new standards see operating and maintaining the asset as implementation aspects and not as relevant decision-making rights of how and for what purpose the asset is used (IASB, 2016, IFRS 16, para. BC120), (FASB, 2016, ASU 2016-02, para. BC137). However, IFRC 4 does not see physical operation of the asset as determinative too (IFRS Interpretations Committee, 2009, IFRIC 4, para. BC31). For wet leases, this gives less importance to the fact a contract may provide for the lessor to operate an aircraft.

While current guidance has a specific consideration of the ability or right to control physical access (criterion No. 2 ), in the new standards this is a consequence of having substantially all of the economic benefits from asset use (FASB, 2016, ASU 2016-02, para. BC38).

Example 7 of the Implementation Guidance of IFRS 16 illustrates an aircraft wet lease that meets the criteria for the definition of a lease even if the supplier has some substitution rights and is responsible for operating the aircraft using its own crew. Under the new standards, wet lease agreements will generally be leases. However, the analysis above shows that a contract analysis is essential: as both parties may have different involvement in significant decisions, the way the contract is structured may lead to the conclusion that the customer does or does not have certain decision-making rights about and for what purpose the asset is used.

The final standards changed the tentative conclusions of the Exposure Draft. Based on the ED, an agreement would have been a service and not a lease when the benefits from use could be obtained only in conjunction with 
additional goods or services that are provided by the supplier and the asset has been designed to function only with such additional goods or services (IFRS, 2013, p. 19). As shown below, the final standards maintain an elaboration of the first of these two criteria as an impediment to the separability of the lease and non-lease components, not as part of the determination of whether the agreement is or contains a lease.

\subsection{Separability of Maintenance and Operation as Non-Lease Components}

Current IFRS and U.S. GAAP require the separation of payments and other consideration into lease and other elements, with an exemption in IFRS to the extent a reliable separation is impracticable (IFRS Interpretations Committee, 2009, IFRIC 4, paras. 13, 15), (FASB, 2018, FASB ASC 840-10-15-10; 840-10-20, 840-10-15-17 to 19). ASU 2016-02 comments that current GAAP does not provide specific guidance as needed about the unit of account for leases (FASB, 2016, ASU 2016-02, para. BC145.b).

Under the new lease standards, once a lessee has determined that the agreement is or contains a lease, it must assess whether the agreement includes components. In this case, under both IFRS 16 and Topic 842 the company will separate non-lease components, account for each separate lease component as a lease and account for non-lease components under the appropriate standard(s). The definition of lease payments in both IFRS 16 and Topic 842 excludes payments allocated to non-lease components, and lease assets and liabilities will not include the consideration attributable to non-lease components. However, the lessee may elect, as a practical expedient (not necessarily because of impracticability), not to make such a separation - an election by class of underlying asset - and account for each lease component and associated non-lease components as a single lease component. The use of such a practical expedient may result in capitalizing services with leases (IASB, 2016, IFRS 16, paras. 12, 15, 16, Appendix A), (FASB, 2018, FASB ASC 842-10-15-28, 31, 37, 842-10-30-6), (IASB, 2016, IFRS 16, Effect Analysis, p. 33). Note that, technically, separability refers to a lease component, not to a non-lease component, while allocation to non-lease components comes consequently.

The first of the two criteria in the new standards, which requires separation of a lease component, is that the lessee must benefit from its use either on its own or with other readily available resources. This means that the lessee has already obtained them or can do so from a third party, which may also be the lessor (IASB, 2016, IFRS 16, para. B32), (FASB, 2018, FASB ASC 842-10-25-28). Therefore, a point that arises regarding the crew and maintenance in an aircraft wet lease is whether to consider such services separate. If the lessee can use its crew, another supplier's crew or the lessor's crew, it is evident that this is a separate non-lease service component. IFRS 16 and Topic 842 show a case of maintenance service, to account for separately because several suppliers provide it, there are observable standalone prices for it and it is practicable for the purchaser to separate the lease from other elements (IASB, 2016, IFRS 16, para. IE4 Example 12), (FASB, 2018, FASB ASC 842-10-55-136).

An issue arises as to whether aircraft operation service should be considered not readily available if the lessee cannot use its own crew or a crew from a supplier other than the lessor, and whether the lessee should determine that the component is not separate.

The analysis of this point must start from the consideration that the new standards have developed from the guidance for revenue multiple-deliverable arrangements, as modified by Topic 606 and IFRS 15. The FASB and the IASB considered appropriate to use similar criteria to those in the new revenue standards for separating performance obligations in revenue contracts with customers, and stated that they expect similar application (IASB, 2016, IFRS 16, para. BC134), (FASB, 2016, ASU 2016-02, paras. BC145-BC146). On the other hand, while this applies at the level of separability of component in a lease, the Boards rejected a fully analogic approach to the revenue standards at the level of definition of a lease. In fact, they stated that the "distinct" requirements in the revenue standards have a different purpose from the issue in the definition of a lease, which focuses on whether the customer has obtained a right to use an asset (IASB, 2016, IFRS 16, para. BC125(b)), (FASB, 2016, ASU 2016-02, para. BC142(b)). In effect, the first criterion for separability in IFRS 16 and Topic 842 somehow corresponds to the so-called Step 1 criterion under IFRS 15 and Topic 606 for a promise of good or service to a customer to be distinct (i.e., capable of being distinct) (IASB, 2016, IFRS 15, para. 27), (FASB, 2018, FASB ASC 606-10-25-19). In this test, the revenue standards infer that a good or service is capable of providing benefits to a customer when the customer can use, consume or sell it for more than scrap value (IASB, 2016, IFRS 15, para. 26), (FASB, 2018, FASB ASC 606-10-20-25). While a good or service that is only capable of providing benefits with another good or service or depends on the entity transferring another good or service is not distinct, on the other hand the analysis must disregard contractual limitation based on which a customer can only obtain readily available resources from the entity (IASB, 2016, IFRS 15, paras. BC97, BC100), (ASU 2014-09, 2014, paras. BC97, B100), (ASU 2016-10, 2016, para. BC33).

The so-called Step 2 in IFRS 15 and Topic 606 instead refers to whether the promise to transfer the good or 
service is distinct within the context of the contract. IASB (2016) Clarifications to IFRS 15 and FASB (2016) ASU 2016-10 has renamed this test as the "separately identifiable principle", i.e., the promise to transfer the individual goods and services is separately identifiable from other promises in the contract. The third indicators of the Step 2 in the revenue standards to signpost that promised goods or services are not separable is that they are highly dependent or interrelated with other goods or services promised in the contract (IASB, 2016, IFRS 15, para. 29(c)), (FASB, 2018, FASB ASC 606-10-25-21). Although the second criterion for separability in the lease standards (i.e., no high dependency or interrelation among underlying assets) is akin to such a third indicator of the Step 2 in the revenue standards, it is limited to the separation of one lease component from another lease component and does not apply to non-lease components. Therefore, there seems to be no explicit guidance in the lease standards on how to treat the fact that the lease component and the service component are bundled or unbundled in the contract.

It is interesting to note the recent amendments to the revenue standards regarding such a Step 2. The fact that a customer could benefit from some services only after it has obtained control of an equipment or is required to use the supplier's services to use the equipment such as, for example, installation services is irrelevant in the analysis of Step 2. In fact, a functional relationship, absent a transformative relationship, would not change the characteristics of goods and services to be capable to be fulfilled independently from each other. It would not mean that they are highly dependent or interrelated if the nature of the promise to the customer within the context of the contract remains to transfer separate items and not a combined item to which the promised goods or services are inputs (IASB, 2016, IFRS 15, paras. 29, BC116K), (FASB, 2018, FASB ASC 606-10-25-21), (FASB, 2016, ASU 2016-10, para. BC29).

\subsection{Operation and Maintenance vs. Executory Costs}

The definition of minimum lease payments in current IFRS excludes costs for services such as insurance and maintenance, as well as the definitions of lease payments and lease income for operating leases do (IASB, 2014, IAS 17, paras. 4, 34, 51), (IFRS Interpretations Committee, 2009, IFRIC 4, para. 13). While IFRS does not use the term "executory" costs, Topic 840 includes insurance and maintenance into executory costs, without making further distinctions. However, substantial services provided by the lessor, such as significant operation services are not executory costs. So, while executory costs incident to the lease component are separated together with a lease component, other services are separated as non-lease components (FASB, 2018, FASB ASC 840-10-25-1, 840-30-30-1, 840-30-50-1, 840-30-30-6, 840-30-50-4, 840-10-55-40, 840-10-15-9).

ASU 2016-02 reports that the distinction between non-lease components and other costs is not clear in current guidance, although it would be positive that maintenance services are non-lease components and not executory costs (FASB, 2016, ASU 2016-02, para. BC157). However, unlike IFRS 16, the Glossary of Topic 842 still maintains the term "executory costs" as an item to be excluded from minimum lease payments and states insurance and maintenance to be paid by the lessee as an example. On the other hand, Topic 842 and the Basis for Conclusions of ASU 2016-02 clarify that maintenance and operations services are service components. Executory costs arise when the lessee pays the lessor for activities or costs of the lessor for which the lessor does not transfer any good or service to the lessee and where the lessor is the primary obligor in the capacity of a lessor or an owner (FASB, 2018, FASB ASC 842-10-15-30), (FASB, 2016, ASU 2016-02, para. BC158).

Unlike non-lease components, administrative tasks (term used in the new standards) do not transfer a good or service to the lessee. The lessee does not allocate any of the consideration to those tasks. The Basis for Conclusions of ASU 2016-02 states, by means of example, that maintenance or operations services are services. IFRS 16 gives the example of a car lease with maintenance services as a lease and a service component, not an administrative task (IASB, 2016, IFRS 16, paras. B33, BC133), (FASB, 2016, ASU 2016-02, para. BC158), (ASBJ, 2014, paras. 11-12). However, while ASC 840-10-15-9 requires adding executory costs incident to the lease component to the lease component, IFRS 16 requires that administrative costs be included in the total consideration before the allocation to the components. Topic 842 and ASU 2016-02 are silent on this respect.

\subsection{Implication of Payment Variability Features of the Contract}

Depending on the contract, the lessor may charge the lessee some amounts on a variable basis for reasons other than the passage of time. IFRS 16 and Topic 842 distinguish between variable payments that do and do not depend on an index or a rate.

Lease payments include variable payments that depend on an index or a rate at the amount resulting from the index or rate at the commencement date but exclude those that do not depend on such parameters. Under Topic 842 , a lessee does not remeasure variable payments that depend on an index or a rate unless it remeasures the lease liability for other reasons (for example, a change in a lease term). Conversely, under IFRS 16, when there 
is a change in the index or rate, the lessee remeasures the lease liability and adjusts the right-to-use asset. However, this only occurs when such a change affects the cash flows as the adjustment takes effect (IASB, 2016, IFRS 16, paras. 27-28, 39, 42, 70, BC163, BC190, BC309), (FASB, 2018, FASB ASC 842-10-15-35 and 36, 842-10-30-5, 842-10-35-4 and 5, 842-10-55-231).

Examples of variable payments that do not depend on an index or a rate are those that depend on the use of the underlying asset or the lessee's performance based on it, for example lessee's sales. So, for example, if the variable payment is subject on the mileage of use of the aircraft by the lessee, this is under the control of the lessee and does not depend on an index or rate.

When instead the variability does reflect an index or rate which is unreasonably low so that it always becomes payable, it may be wondered whether this is an in-substance fixed payment that must anyway be included in the lease payments. In fact, a variable payment will be treated as in-substance fixed if it is variable only in form, but in effect unavoidable (IASB, 2016, IFRS 16, paras. 27, 70, B42), (FASB, 2018, FASB ASC 842-10-15-35; 842-10-30-5; 842-10-55-31).

IFRS 16 requires that a lessee recognize variable payments not based on an index or rate upon occurrence of the fact triggering them (IASB, 2016, IFRS 16, paras. 38, IE6 Example 14). The following discussion refers to such types of variable payments. Topic 842 requires a lessee to recognize them in profit or loss when it incurs the related obligation, with an accrual before the achievement of the target triggering the payment, provided it is considered probable (FASB, 2018, FASB ASC 842-20-25-5 and 6, 842-20-55-1 and 2, 842-10-55-234).

Both IFRS 16 and Topic 842 refer to variable payments for the right to use an underlying asset, not for services (unlike IASB, 2016, IFRS 16, para. Appendix A, FASB, 2018, FASB ASC 842-10-30-6, 842-20-20 say it explicitly). Therefore, it is important to ascertain what these payments are for. If variable payments not based on an index or rate do not specifically relate to services, they will be allocated on the same base as the initial allocation of the consideration in the contract among lease and non-lease components (see FASB, 2018, FASB ASC 842-10-55-151 as an example). If such payments are indeed for services but the lease does not qualify for separability of lease-component from non-lease components or the lessee elects the practical expedient not to make such a separation, the determination of how to account for variability will also affect the lease. Conversely, a variable payment that exclusively relates to separate services will follow the standard(s) applicable for the respective non-lease component them (IASB, 2016, IFRS 16, para. IE4 Example 12).

Unlike a lessee, a lessor considers the guidance on revenue from contracts with customers under IFRS 15 and Topic 606 in allocating the consideration in the contract among lease- and non-lease components. In this respect, Topic 842 is more specific than IFRS 16. It explains that for the purpose of initial allocation the consideration in the contract also comprises variable payments that would be included in the transaction price based on such revenue guidance on variable consideration. However, this holds only if they specifically relate to either lessor's efforts to transfer non-lease goods or services or to an outcome from such transfers (FASB, 2018, FASB ASC 842-10-15-39 to 40), (FASB, 2016, ASU 2016-02, para. BC162). Topic 842 gives an example of variable payments for highly specialized maintenance services without which the equipment would not perform appropriately. Such variable payments do not refer to lease components. The lessor includes them in the initial consideration in the contract but allocates them entirely to the non-lease components they specifically refer to, unless a different allocation is required to meet the allocation objective in the mentioned revenue standards. This objective affirms that the allocation should reflect the consideration the entity expects to be entitled in exchange for transferring the promised goods or services to the customer. This means that under certain circumstances specific non-lease components may still affect the lease components. The lessor will then follow the appropriate revenue recognition guidance to recognize the non-lease component (IASB, 2016, IFRS 16, para. 17), (IASB, 2016, IFRS 15, para. 73), (FASB, 2018, FASB ASC 606-10-32-28, 842-10-55-153 to 156).

Conversely, the lessor must exclude from lease payments a variable payment that even partially relates to a lease component and must recognize it only upon the occurrence of the facts and circumstances triggering the payment. When and if such a payment is earned, the lessor will allocate it based on the same allocation proportion between separate lease and non-lease payments as done initially. As an example, Topic 842 illustrates a variable payment that is due when the equipment is operating a minimum number of hours at a specified level of productivity. It interprets it as being not related only to performance of maintenance services but also to the quality and condition of the underlying asset, as both may contribute to make the equipment not malfunctioning or inoperable. Topic 842 also mentions the case for variable payments that depend on the lessee's sales (FASB, 2018, FASB ASC 842-10-55-152), (FASB, 2016, ASU 2016-02, para. BC162). A lessor's subsequent recognition of variable payments that are not included in the lease payments and so are not part of the net 
investment in the lease occurs upon occurrence of the facts and circumstances on which they are based (FASB, 2018, FASB ASC 842-30-25-2, 842-30-25-9, 842-30-25-11).

If variable lease payments are based on a contingency (such as performance of the use of the underlying asset) and the contingency is resolved so that the payment becomes fixed, the lessee must remeasure the lease payments (FASB, 2018, FASB ASC 842-10-35-4(b)).

Under U.S. GAAP, variable lease payments depending on an index or rate that meet the definition of an embedded derivative should be analyzed for separation from the lease and accounted for under the guidance for financial instruments (FASB, 2016, ASU 2016-02, paras. BC118-BC119). However, U.S. GAAP, IFRS 9 and IAS 39 state that variable lease payments embedded in a host lease and that are based on variable interest rates are not separated as considered closely and closely related to the economic characteristics and risks of the host contract. Similarly, payments that are based on related sales are not separated (IASB, 2016, IFRS 9, para. B.4.3.8(f)), (IASB, 2016, IAS 39, para. AG33), (FASB, 2018, FASB ASC 815-15-25-22, 815-15-55-7).

The lessee and the lessor must disclose the amounts of variable payments expenses and income, respectively. In the statement of cash flows, the lessee classifies them as operating cash flows. The lessee must also provide several disclosures as to their reasons, prevalence, key variables, effects of variable payments, and cash flow exposure. The lessor also gives indications of the role of such payments in its risk management strategy (IASB, 2016, IFRS 16, paras. 50, 53, 59, 90, 92, BC169, IE9 Example 22), (FASB, 2018, FASB ASC 842-20-50-3 to 4, 842-30-50-3, 842-30-50-5 and 7).

Extant GAAP differ from the new guidance under several respects. IAS 17 uses the term "contingent" rents for a payment that is not fixed in amount because its changes go with the future levels of a factor that are unrelated to the passage of time. Unlike IFRS 16, this notion captures variability both related to sales or the use of the underlying asset and to indexes or rates. A lessee excludes contingent rents from minimum lease payments. For a finance lease, it recognizes them as expenses in the periods in which they are incurred and explains them in the notes. In the case of an operating lease, it also discloses their amounts separately from the total lease expenses. In both cases, it explains the basis for determining contingent rent payable. Likewise, the lessor discloses contingent rent income (IASB, 2014, IAS 17, paras. 4, 25, 31, 35, 47, 56).

Under Topic 840, contingent rentals include lease payments that vary with the use of the leased property or with sales volumes, only the initial, not subsequent, measurement of lease payments that vary based on an index or rate and exclude escalation of minimum lease payments due to increases in acquisition or construction cost (FASB, 2018, FASB ASC 840-10-20; 840-10-35-4).

\subsection{What Companies Disclose about Their Accounting for Wet Leases}

Sampled companies report that they use or furnish wet leases (some with detail of which aircraft, generally in management commentary). Although they illustrate the accounting policies for finance and operating leases in general and break down the aircraft fleet as owned or held under finance or operating leases, only a few companies explicitly disclose some accounting treatments used for wet leases. A thing that an analyst can do is to look at which caption of the income statement includes leases costs, to derive whether they are part of depreciation (an indicator of finance lease classification under extant GAAP) or other operating costs (an indicator of operating lease categorization, but also of treatment as a service contract). A few companies give separate disclosure. Meridiana Fly separately discloses operating costs, revenues, accounts payables and accounts receivables relating to passive and active wet leases, respectively. Turkish Airlines discloses wet leases expenses, classified separately from operating leases. Conversely, most sampled lessors generally disclose their revenue recognition policy for wet and dry leases.

\section{Research Question No. 3: Accounting Business Model Views Conflict with Travelers' View}

\subsection{Issues Concerning the Travelers' Perspectives}

From a traveler's perspective, the choice of an airline to a certain extent reflects considerations of safety and level of customer service. At least, these are sanitation factors that, if missing, would discourage travelling with that airline.

Parasuraman et al. (1988) proposed a SERVQUAL model with five constructs of tangibles, reliability, responsiveness, assurance, and empathy for a conceptualization model of service quality. There are some applications of the SERVQUAL model to airlines, such as Pakdil at al. (2007) who applied it to a Turkish airline, Chou et al. (2011), and Huang (2010). Chen at al. (2017) applied the SERVQUAL model to the aviation industry to include security and safety in reliability and communication in empathy. They report that security and safety accounts for $59.1 \%$ of respondents in choosing an airline and this is the highest concern in terms of management 
issues for the worldwide airlines.

Atahk at al. (2009) found that passengers assign flight safety and security the highest ranking among the elements of service provided by airlines. Their model also shows that safety services have a positive influence on loyalty level.

Although the safety and legal requirements of wet leases are strictly regulated (EC Regulation No. 1008/2008); (EC Regulation No. 859/2008); (Geneva Convention, 1948); (UK SI 2009 No. 41); (Cini Chacko, 2011), knowing that an aircraft is not part of the permanent fleet of an airline and that is operated by a third party may be of some concern to travelers.

It is general held that, with regards to code-shared flights, information provided to the public regarding the identity of the companies involved in a flight needs to be improved. (ICAO's Circular 269-AT/ $/ 10$, page 34), however a similar conclusion can be applied to wet leases. This argument, which applies to flights, can be also translated at the level of the whole company information to the public.

It is well known the 2013 case of a wet lease operated by Carpatair in wet lease for Alitalia, where soon after a runaway excursion incident Alitalia removed its livery from the aircraft to avoid customers blaming the company and soon after suspended the wet lease agreement (Carpatair, 2013). In that occurrence, the public opinion even arrived to allege fraud for the case of an aircraft being operated by another company than the one marketed.

\subsection{The Debate about Services in Leases and Users' Perspective in Disclosure Requirements}

There has been some debate about the role of services in a wet lease at to whether they qualify as an asset or a service. The Basis for Conclusions of ASU 2016-02 reports that some see a blurred difference between services and operating leases (FASB, 2016, ASU 2016-02, para. BC43). The EFRAG reports the view of some constituents based on which mingling the use of the asset with service features in a wet lease would be equivalent to a single unit of account service agreement or, depending on the circumstances, to an asset with incidental service, or even separate lease and service contracts. The former case would exist to the extent the customer cannot outsource the services to other suppliers, the services cannot be separated from the use of the asset, the supplier has a significant continuing involvement in operating and maintaining the asset other than ordinary warranty, or the risks of operating and making the asset available remain with the supplier. Missing those characteristics, services would be incidental to the use of the asset (EFRAG, 2013, paras. 24-26, 28). Some respondents have expressed the opinion that a lessee in a wet lease seeks a service, which is the predominant feature of the agreement (EFRAG, 2014, paras. 16, 20).

Although the new lease standards have not followed such directions, IFRS 16.59, 92 include the requirement to disclose the nature of leasing activities by lessees and lessors, respectively, but this is a residual and minimum requirement.

\subsection{Company Disclosures}

The analysis of the sampled companies has found no discussion, explanation or analysis even in management commentary about wet leases with reference to safety procedures, customer service aspects or other customer issues. From this, it may be concluded that, in general, companies' disclosures are not transparent enough to make customers understand that an airline uses wet leases and how this may affect the customer's experience.

\section{Results, Discussion and Conclusions}

This article has analyzed the dystonia among three different views of services in leases: the competitive, the accounting, and the customers' views. This has been illustrated by the case of aircraft wet leases. The Appendix summarizes the study of financial statements by individual company.

This article has obtained several new findings, as follows.

Technical accounting analysis

To the knowledge of the author, this is the first time that a thorough analysis of IFRS 16 and Topic 842 has been publicly applied to wet leases. The technical accounting analysis shows that these contracts are leases under those standards. However, companies have some latitude in structuring variable payments to capture them or not in lease components.

\section{Accounting disclosures and limits of the new standards in disclosing the role of services in leases}

The research of sampled financial statements has found limited accounting disclosure for wet leases, because they are not separated from other leases for which disclosures are provided.

IFRS 16.59 compliments certain additional qualitative and quantitative disclosures that may give lessees a way 
to disclose some aspects of services in leases, including the nature of leasing activities, variable lease payments, and restrictions or covenants. As to lessors, IFRS 16.92 has similar additional disclosure requirements, also including risk of management of the underlying assets, for example, variable lease payments for use in excess of specified limits. However, these additional disclosures do not really cover the peculiarities of wet leases and leases with significant services and, anyway, must only be provided to the extent necessary to meet the disclosure objectives of facilitating the assessment of the effect of leases on the financial position, financial performance and cash flows of the lessee and the lessor, respectively (IFRS 16.51, 89). So, they do not tackle aspects such as the provision of services and the effect on a business model, even though such features may be critical for an investor in assessing the financial success of the reporting entity.

\section{Competitive and business model role of wet leases}

The analysis of the competitive view has moved from the characteristics of wet lease contracts and how they may serve a temporary, agile, competitive use in an airline business model. Companies disclosures, albeit limited and mainly in management commentary (which is outside of IFRS and U.S. GAAP financial statements), confirm their use in this sense in the airline business model. This view clearly contrasts with the accounting view of permanent assets of a company. The paucity in disclosing these aspects may be an indicator of resistance to provide competitive and non-customer-oriented information, due to the sensibility of the topic for customers and confidentiality of information for competitors.

\section{Dystonia with customer service view}

The accounting and business model views are different from a service and safety perspective, which focuses on the service and safety risks of outsourcing the operation and maintenance of aircraft.

The potential negative perception on the use of wet leases may reasonably be one of the explanations why information on wet lease impact on service and security is so little in financial reports. The accounting view and the competitive models are clearly in potential conflict with considerations that wet leases may raise on travelers.

The consequence of the importance of different types of users in the Conceptual Framework

The role of service as a determinant of lease classification and accounting has not been supported by the IASB and the FASB. The new lease standards have resolved the debate about significant services by confirming the nature of a right of use as an asset for a lessee. This is supposed to be consistent with an economic view from the perspective of existing and potential investors, lenders and creditors, which the IASB and FASB Conceptual Frameworks consider as primary users of general purpose financial reports that are not primarily directed to other members of the public, including customers (IASB, 2018, Conceptual Framework 2018, 1.5, 1.10; IASB, 2010, Conceptual Framework 2010 and FASB, 2010, CON 8, OB2, OB5, OB10).

While the Conceptual Frameworks admit that there may be conflict between information needs of users (IASB, 2018, Conceptual Framework 2018, 1.8; IASB, 2010, Conceptual Framework 2010 and FASB, 2010, CON 8, $\mathrm{BC} 1.18$ ), customers' expectations and perception of safety and service levels of third-party operated assets will also affect customers' demand and therefore revenue and company's prospects for future net cash inflows, which according to the Framework is the main driver of investors and creditors decision making (IASB, 2018, Conceptual Framework 2018, 1.3; IASB, 2010, Conceptual Framework 2010 and CON 8, OB3). In conclusion, competitive business model and service aspects of wet leases are not given enough space to represent the indirect effects on the financial statements, which in this respect seem to be not fully fit for purpose to serve the objective informed on by the IASB and FASB Conceptual Frameworks.

\section{References}

Altamuro, J., Johnston, R., Pandit, S., \& Zhang, H. (2014). Operating leases and credit assessments. Contemporary Accounting Research, 31(2), 551-580. http://dx.doi.org/10.1111/1911-3846.12033

Andrikopoulos, A., \& Markellos, R. N. (2014). Dynamic interaction between markets for leasing and selling automobiles. Journal of Banking \& Finance, 50, 260-270. https://doi.org/10.1016/j.jbankfin.2014.01.032

Arnold, C., \& Tahtah, J. (2017). De invloed van IFRS 16 leases op de jaarrekening van lessees (The impact of IFRS 16 Leases on the financial statements of lessees). Maandblad voor accountancy en bedrijfseconomie, 91(11/12), 376-391.

Atalık, Ö., \& Arslan, M. (2009). A Study to Determine the Effects of Customer Value on Customer Loyalty in Airline Companies Operating: Case of Turkish Air Travellers. International Journal of Business and Management, 4(6), 1-9. http://dx.doi.org/10.5539/ijbm.v4n6p154

Bohušováa, H. (2015). Is capitalization of operating lease way to increase of comparability of financial 
statements prepared in accordance with IFRS and US GAAP? Acta Universitatis Agriculturae et Silviculturae Mendelianae Brunensis, 63(2), 507-514. https://doi.org/10.11118/actaun201563020507

Bohušováa, H., Svobodaa, P., \& Blaškováb, V. (2014). The uncertainty associated with the estimated lease term and its impact on financial statements items. Enterprise and the Competitive Environment 2014. Paper presented at the ECE 2014 Conference, 6-7 March 2014, Brno, Czech Republic. Procedia Economics and Finance, 12, 76-84. http://dx.doi.org/10.1016/S2212-5671(14)00322-0

Bourjade, S., Huo, R., \& Muller-Vibes, C. (2017). Leasing and Profitability: Empirical Evidence from the Airline Industry. Transportation Research Part A: Policy and Practices, 97, 30-46. https://doi.org/10.1016/j.tra.2017.01.001

Briggs, J., Beams, J., Baril, C. P., \& Betancourt, L. (2017). Variable lease payments: Implications under the new lease standards. The CPA Journal, 2, 38-45.

Chen, C. M., \& Liu, H. M. (2017). Exploring the Impact of Airlines Service Quality on Customer Loyalty: Evidence from Taiwan. International Journal of Business and Management, 12(5), 36-50. http://dx.doi.org/10.5539/ijbm.v12n5p36

Chou, C. C., Liu, L. J., Huang, S. F., Yih, J. M., \& Han, T. C. (2011). An Evaluation of Airline Service Quality using the Fuzzy Weighted SERVQUAL method. Applied Soft Computing, 11(2), 2117-2128. http://dx.doi.org/10.1016/j.asoc.2010.07.010

Cini, C. M. (2011). Aircraft Leasing and Financing, Emerging Issues and Concerns. Paper presented at Conference on Emerging Needs and Demands of Airports and Airlines - A Global Perspective, India.

Convention on the International Recognition of Rights in Aircraft (Geneva Convention). (1948). Geneva.

EFRAG Secretariat. (2013). Staff of Exposure Draft Leases: Definition of a Lease - What Makes a Difference between a Service and a Lease? Retrieved from http://www.efrag.org

EFRAG. (2014). Feedback Report, Exposure Draft Leases, Results of the Additional Public Consultation on Lessee Accounting Carried out by EFRAG, ANC, ASCG, FRC and OIC. Retrieved from http://www.efrag.org

Ericson, J., \& Skarphagen, R. (2015). Capitalization of operating lease and its impacts on financial ratios (Unpublished master's thesis). Jörköping University Jörköping International Business School, Jönköping, Sweden.

European Commission. (2008). EC Regulation No. 1008/2008 of 24 September 2008 on common rules for the operation of air services in the Community. Luxembourg: The Publications Office of the European Union.

European Commission. (2008). EC Regulation No. 859/2008 of 20 August 2008 amending Council Regulation (EEC) No 3922/91 as regards common technical requirements and administrative procedures applicable to commercial transportation by aero plane. Luxembourg: The Publications Office of the European Union.

Financial Accounting Standards Board. (2003). EITF Issue No. 01-8, Determining Whether and Arrangement Contains a Lease (EITF 01-8), codified in Subtopic 840-10. Retrieved from http://www.fasb.org

Financial Accounting Standards Board. (2014). Accounting Standards Update No. 2014-09, Revenue from Contracts with Customers (Topic 606) (ASU 2014-09). Retrieved from http://www.fasb.org

Financial Accounting Standards Board. (2016). Accounting Standards Update No. 2016-02, Leases (Topic 842) (ASU 2016-02). Retrieved from http://www.fasb.org

Financial Accounting Standards Board. (2016). Accounting Standards Update No. 2016-10, Revenue from Contracts with Customers (Topic 606) - Identifying Performance Obligations and Licensing (ASU 2016-10). Retrieved from http://www.fasb.org

Financial Accounting Standards Board. (2018). FASB Accounting Standards Codification (FASB ASC). Retrieved from http://www.fasb.org

Gross, A. D., Huston, G. R., \& Huston, J. M. (2014). The Path of Lease Resistance: How Changes to Lease Accounting Treatment May Impact Your Business. Business Horizons, 57(6), 759-765. http://dx.doi.org/10.1016/j.bushor.2014.06.006

Hengen, N. L. (2007). Maritime Financing. In Norton, J. J., T. E. Gillespie, \& D A. Rice (Eds.), Commercial Finance Guide (Chapter 5). New York: M. Bender. 
Hsieh, S., \& Su, Y. (2015). The Economic Implications of the Earnings Impact from Lease Capitalization. Advances in Accounting, 31(1), 42-54. http://dx.doi.org/10.1016/j.adiac.2015.03.003

Huang Y. K. (2010), The Effect of Airline Service Quality on Passengers' Behavioural Intentions Using SERVQUAL Scores. Journal of the Eastern Asia Society for Transportation Studies, 8.

ICAO. (1997). Circular 269-AT/10, Implications of Airline Codesharing. Canada: Secretary General.

IFRS Interpretations Committee. (2009). IFRIC 4, Determining whether and Arrangement contains a Lease (IFRC 4). Retrieved from http://www.fasb.org

International Accounting Standards Board. (2010). Conceptual Framework for Financial Reporting 2010 (Conceptual Framework 2010). Retrieved from http://www.fasb.org

International Accounting Standards Board. (2013). Exposure Draft, Leases. Retrieved from http://www.fasb.org

International Accounting Standards Board. (2014). International Accounting Standard 17, Leases - as Amended (superseded) (IAS 17). Retrieved from http://www.fasb.org

International Accounting Standards Board. (2016). Clarifications to IFRS 15, Revenue from Contracts with Customers (Clarifications to IFRS 15). Retrieved from http://www.fasb.org

International Accounting Standards Board. (2016). International Accounting Standard 39, Financial Instruments: Recognition and Measurement - as Amended (superseded) (IAS 39). Retrieved from http://www.fasb.org

International Accounting Standards Board. (2016). International Financial Reporting Standard 9, Financial Instruments - as Amended (IFRS 9). Retrieved from http://www.fasb.org

International Accounting Standards Board. (2016). International Financial Reporting Standard 15, Revenue from Contracts with Customers - as Amended (IFRS 15). Retrieved from http://www.fasb.org

International Accounting Standards Board. (2016). International Financial Reporting Standards 16, Leases (IFRS 16). Retrieved from http://www.fasb.org

International Accounting Standards Board. (2018). Conceptual Framework for Financial Reporting (Conceptual Framework 2018). Retrieved from http://www.fasb.org

La Spina, M. P. (2011). Cenni su alcune figure contrattuali atipiche nel trasporto aereo. Giureta. Rivista di Diritto dell'Economia, dei Trasporti e dell'Ambiente, 9, 207-219.

Lim, C. S., Mann, \& S. C., Mihov, V. T. (2017). Do Operating Leases Expand Credit Capacity? Evidence from Borrowing Costs and Credit Ratings. Journal of Corporate Finance, 42, 100-114. https://doi.org/10.1016/j.jcorpfin.2016.10.015

Masaki, K. (2017). Effect of Capitalizing Operating Leases on Credit Ratings: Evidence from Japan. Journal of International Accounting, Auditing and Taxation, 30, 45-56. https://doi.org/10.1016/j.intaccaudtax.2017.12.008

Morales-Diaz, J. (2018). The Impact of IFRS 16 on Key Financial Ratios: A New Methodological Approach. Accounting in Europe, 15(1), 105-133. https://doi.org/10.1080/17449480.2018.1433307

Nuryani, N., Heng, T. T., \& Juliesta, N. (2015). Capitalization of Operating Lease and Its Impact on Firm's Financial Ratios. Paper presented at the 2nd Global Conference on Business and Social Science-2015, GCBSS-2015, 17-18 September 2015, Bali, Indonesia. Procedia - Social and Behavioral Sciences, 211, 268-276. http://dx.doi.org/10.1016/j.sbspro.2015.11.034

Öztürk, M., \& Serçemeli, M. (2016). Impact of New Standard "IFRS 16 Leases" on Statement of Financial Position and Key Ratios: A Case Study on an Airline Company in Turkey. Business and Economics Research Journal, 7(4), 143-157. http://dx.doi.org/10.20409/berj.2016422344

Padkil, F., \& Aydin, Ö. (2007). Expectations and Perceptions in Airline Services: An Analysis Using weighted SERVQUAL Scores. Journal of Air Transport Management, 12(4), 229-237. https://doi.org/10.1016/j.jairtraman.2007.04.001

Parasuraman, A., \& Ziethaml, V. (1988). SERVQUAL: A Multiple- Item Scale for Measuring Consumer Perceptions of Service Quality. Journal of Retailing, 62(1), 12-40.

Sacarin, M. (2017). IFRS 16 "Leases" - Consequences on the Financial Statements and Financial Indicators. The Audit Financial Journal, 15(145), 114-122. https://doi.org/10.20869/AUDITF/2017/145/114 
Sarı, E., S., Altintaş, T., \& Tas, N. (2016). The effect of the IFRS 16: Constructive capitalization of operating leases in the Turkish retailing sector. Journal of Business, Economics and Finance, 5(1), 138-147. https://doi.org/10.17261/Pressacademia.2016116657

Tai, B. Y. (2013). Constructive capitalization of operating leases in the Hong Kong fast-food industry. International Journal of Accounting and Financial Reporting, 3(1), 128-142. http://dx.doi.org/10.5296/ijafr.v3i1.3270

UK Civil Aviation. (2009). Statutory Instrument SI 2009 No. 41, Regulation of the operation of air services in the Community Regulations 2009.

Vakhitov Damir, R. A., \& Zamaletdinov A. (2014). Leasing as a Factor of Economic Growth. Paper presented at the 2nd Global Conference on Business, Economics, Management and Tourism, 30-31 October 2014, Prague, Czech Republic.

Wei-Tung, C., Kuancheng, H., \& Ardiansyah, M. N. (2018). A mathematical programming model for aircraft leasing decisions. Journal of Air Transport Management, 69, 15-25. http://dx.doi.org/10.1016/j.jairtraman.2018.01.005

Wong, K., \& Joshi, M. (2005). The impact of lease capitalisation on financial statements and key ratios: Evidence from Australia. Australasian Accounting, Business and Finance Journal, 9(3), 26-44. http://dx.doi.org/10.14453/aabfj.v9i3.3

Zhang, Y., Zhang, W., Xu, W., \& Li, H. (2011). Competitive Strategy for the on-line Leasing of Depreciable $\begin{array}{llll}\text { Equipment. Mathematical and Computer Modelling, 54(1), 466-476. } & \text {. }\end{array}$ http://dx.doi.org/10.1016/j.mcm.2011.02.036

\section{Appendix}

Wet Lease Disclosures

\begin{tabular}{|c|c|c|c|c|}
\hline Company & Document & & GAAP & Disclosures of accounting for wet leases \\
\hline Aegean & $\begin{array}{l}\text { Annual } \\
2014\end{array}$ & Report & IFRS & $\begin{array}{l}\text { "In } 2010 \text { and } 2011 \text { the Company also used } 2 \text { and } 3 \text { aircraft respectively under } \\
\text { short-term wet lease agreement (ACMI) to cover the needs of charter operation." } \\
\text { (P 29). No explanation of accounting for wet leases was found in the financial } \\
\text { statements. }\end{array}$ \\
\hline Aeroméxico & $\begin{array}{l}\text { Annual } \\
2017\end{array}$ & Report & IFRS & The financial report only mentions a wet lease (P. 65). \\
\hline Air Arabia & $\begin{array}{l}\text { Consolidat } \\
\text { Financial } \\
\text { Statements }\end{array}$ & & IFRS & $\begin{array}{l}\text { The financial report mentions wet leases (P. 34) but does not provide details of } \\
\text { the accounting. }\end{array}$ \\
\hline Air Berlin & $\begin{array}{l}2015 \\
\text { Report }\end{array}$ & Annual & IFRS & $\begin{array}{l}\text { The financial report mentions a long-term wet lease (P 24) and defines a wet } \\
\text { lease (P. 168) but does not provide detail of the accounting. }\end{array}$ \\
\hline Air Canada & $\begin{array}{l}2017 \\
\text { Report }\end{array}$ & Annual & IFRS & $\begin{array}{l}\text { The financial report does not report wet leases, but capacity purchase } \\
\text { arrangements with regional airlines operating flights on behalf of the company, to } \\
\text { get greater network flexibility, fleet economics, pilot mobility, lower-density } \\
\text { markets and higher-density markets at off-peak times and traffic feed. The } \\
\text { company states that it will have a right-of-use asset and lease liability under } \\
\text { IFRS } 16 \text { (Pp. 12, 15, 59, 66, 89) }\end{array}$ \\
\hline Air China & $\begin{array}{l}\text { Annual } \\
2016\end{array}$ & Report & IFRS & $\begin{array}{l}\text { The financial report mentions that the company has aircraft under wet leases and } \\
\text { also leases out aircraft under wet lease (Pp. 12, 14, 25, 27). However, no } \\
\text { explanation has been found on how they are accounted for or other related } \\
\text { disclosures. }\end{array}$ \\
\hline Air India & $\begin{array}{l}\text { Financial } \\
\text { Statements }\end{array}$ & & $\begin{array}{l}\text { Indian } \\
\text { GAAP }\end{array}$ & P. 90 mentions wet leases. No explanation of accounting for wet leases. \\
\hline Air Lingus & $\begin{array}{l}\text { Directors' } \\
\text { and FS } 31 \\
\text { and } 2016\end{array}$ & $\begin{array}{r}\text { report } \\
12 / 2015\end{array}$ & IFRS & $\begin{array}{l}\text { It reports damp leases by aircraft type (in } 2016 \text {, wet leases). Aircraft operating } \\
\text { lessor billing in advance are recorded as deferred revenue. "Other revenue" and } \\
\text { costs are recognized as services are provided (2015: P. 8, 35) (2016: P.6, 26). }\end{array}$ \\
\hline Alitalia & $\begin{array}{l}\text { Cons. } \\
31 / 12 / 14\end{array}$ & Report & $\begin{array}{l}\text { Italian } \\
\text { GAAP }\end{array}$ & $\begin{array}{l}\text { The financial report defines ACMI and wet leases and mentions the use of wet } \\
\text { lease services (Pp. 163, 214, 218). }\end{array}$ \\
\hline
\end{tabular}




\begin{tabular}{|c|c|c|c|}
\hline Company & Document & GAAP & Disclosures of accounting for wet leases \\
\hline $\begin{array}{l}\text { Alliance Aviation } \\
\text { Services }\end{array}$ & $\begin{array}{l}\text { Annual Report } \\
2015\end{array}$ & RS & $\begin{array}{l}\text { The financial report defines ACMI leases and states that the company flies wet } \\
\text { lease hours on behalf of other operators }(\mathrm{Pp} .5,32) \text {. }\end{array}$ \\
\hline American Airlines & $\begin{array}{l}\text { Form } 10-\mathrm{K} \text {, Year } \\
\text { Ended December } \\
31,2016\end{array}$ & $\begin{array}{l}\text { U.S. } \\
\text { GAAP }\end{array}$ & $\begin{array}{l}\text { The financial report does not report wet leases, but capacity purchase } \\
\text { arrangements where the company recognizes all revenues, and regional expenses } \\
\text { for predetermined fixed fees to the operating airlines and certain variable costs. It } \\
\text { discloses minimum fixed obligations under capacity purchase agreements (Pp. 5, } \\
39,148,174-175) \text {. }\end{array}$ \\
\hline $\begin{array}{l}\text { Atlas Air World } \\
\text { Wide Holdings }\end{array}$ & $\begin{array}{l}2009 \\
\text { Report }\end{array}$ & $\begin{array}{l}\text { U.S. } \\
\text { GAAP }\end{array}$ & $\begin{array}{l}\text { It defines ACMI and Dry leases. ACMI revenue is recognized as Block Hours are } \\
\text { operated, with minimum contracted guarantee floor. Dry lease revenue is } \\
\text { recognized as operating lease under ASC } 840 \text {. Additional rental based on usage is } \\
\text { recorded as revenue as earned }(\mathrm{P} .2,29,60) \text {. }\end{array}$ \\
\hline Cargojet Inc & $\begin{array}{l}\text { Information Form } \\
31 / 12 / 2014\end{array}$ & IFRS & $\begin{array}{l}\text { Financial statements define wet leases, give details of length of operating leases, } \\
\text { but no explanation of which wet leases and its accounting are (P. 10) }\end{array}$ \\
\hline Cathay Pacific & $\begin{array}{l}\text { Annual } \\
2015\end{array}$ & HKFRS & $\begin{array}{l}\text { The financial report details the aircraft operated as wet leases and as dry leases } \\
\text { (P. 13) }\end{array}$ \\
\hline Easyjet & $\begin{array}{l}\text { Annual Report and } \\
\text { Accounts } 2017\end{array}$ & & $\begin{array}{l}\text { The financial report defines wet and dry leases and mentions wet leases to add } \\
\text { flexibility into the schedule and to build peak season resilience. It also mentions } \\
\text { dry leases and reports the related revenues and costs as separate lines in the } \\
\text { income statement and classifies costs as part of ownership costs (Pp. 11, 14, 17, } \\
26,28,29,87,94,95,100,136) \text {. }\end{array}$ \\
\hline El Al Israel Airlines & 2014 report & IFRS & The Company leases cargo aircraft in wet lease (Note 8.10). \\
\hline Finnair & $\begin{array}{ll}\text { Fin. } \quad \text { Statements } \\
2015\end{array}$ & IFRS & $\begin{array}{l}\text { The financial statements report payments for wet lease within lease expenses in } \\
\text { operational expenses (P. 25). }\end{array}$ \\
\hline $\begin{array}{l}\text { Flybe } \\
\text { Limited }\end{array}$ & $\begin{array}{l}\text { Consolidated FS } \\
31 \text { March } 2010\end{array}$ & $\begin{array}{l}\text { UK } \\
\text { GAAP }\end{array}$ & Financial statements mention wet leases (Pp. 3-4) \\
\hline $\begin{array}{l}\text { International } \\
\text { Airlines Group }\end{array}$ & $\begin{array}{l}\text { Annual report and } \\
\text { accounts } 2016\end{array}$ & IFRS & ). \\
\hline $\begin{array}{l}\text { Jet Airways (India) } \\
\text { Limited }\end{array}$ & $\begin{array}{l}\text { Annual } \\
2014\end{array}$ & $\begin{array}{l}\text { Indian } \\
\text { GAAP }\end{array}$ & $\begin{array}{l}\text { It details aircraft given on dry and wet lease and their future minimum lease } \\
\text { income }(\mathrm{Pp} .18,81) \text {. They are classified as operating leases. }\end{array}$ \\
\hline Lufthansa Group & $\begin{array}{l}\text { Annual } \\
2016\end{array}$ & IFRS & $\begin{array}{l}\text { The financial report defines a wet lease (P. 193) and explains the wet lease } \\
\text { agreement from Air Berlin to the Group companies Eurowings, Austrian Airlines } \\
\text { (Pp. 27, 28, 41). }\end{array}$ \\
\hline Meridiana Fly & $\begin{array}{l}\text { Annual Financial } \\
\text { Report } 2012\end{array}$ & IFRS & $\begin{array}{l}\text { It defines and explains active and passive ACMI and long-term wet leases. } \\
\text { Revenues from sales includes ACMI revenues. EBITDAR - Earnings Before } \\
\text { Interest, Taxes, Depreciation, Amortization and Aircraft Rentals has wet leases } \\
\text { separately but excludes operating leases and provision for liabilities and charges. } \\
\text { ACMI receivables and payables are separately reported (Pp. 2, 9, 20-21, 112, } \\
\text { 122, 202-203). }\end{array}$ \\
\hline $\begin{array}{l}\text { Norvegian } \\
\text { Shuttle Asa }\end{array}$ & $\begin{array}{l}\text { Annual } \\
2015\end{array}$ & IFRS & $\begin{array}{l}\text { Other revenue also comprises wet lease. Aircraft lease expenses includes } \\
\text { wet-lease costs as operating cost (Pp. } 35,67) \text {. }\end{array}$ \\
\hline Oman Air & $\begin{array}{l}\text { Annual } \\
2014\end{array}$ & IFRS & $\begin{array}{l}\text { Financial statements mention wet leases (P. 24) but do not provide explanation } \\
\text { on the accounting. }\end{array}$ \\
\hline Qantas & Data Book 2012 & $\begin{array}{l}\text { AASBs } \\
\text { and IFRS }\end{array}$ & $\begin{array}{l}\text { The financial report defines a wet lease and giving details of the active } \\
\text { wet-leased and dry-leased fleet (Pp. 20, 37). }\end{array}$ \\
\hline SAS & Report 2015/ 2016 & IFRS & $\begin{array}{l}\text { The financial report defines wet leases and describes aircraft and other aspects } \\
\text { (Pp. 12, 16, 23, 26, 36, 104). }\end{array}$ \\
\hline Shandong Airlines & $\begin{array}{l}\text { Annual } \\
2015\end{array}$ & & $\begin{array}{l}\text { Financial statements mention wet leases (P. 4) but do not provide explanation on } \\
\text { the accounting. }\end{array}$ \\
\hline Sprint Airlines & 10-Q 03/14 & $\begin{array}{l}\text { U.S. G } \\
\text { AAP }\end{array}$ & Financial statements define a wet lease (P. 20). \\
\hline TNT & $\begin{array}{l}\text { Annual } \\
2015\end{array}$ & IFRS & $\begin{array}{l}\text { Other operating revenue also includes wet leases of aircraft for third parties (P. } \\
76) \text {. }\end{array}$ \\
\hline
\end{tabular}




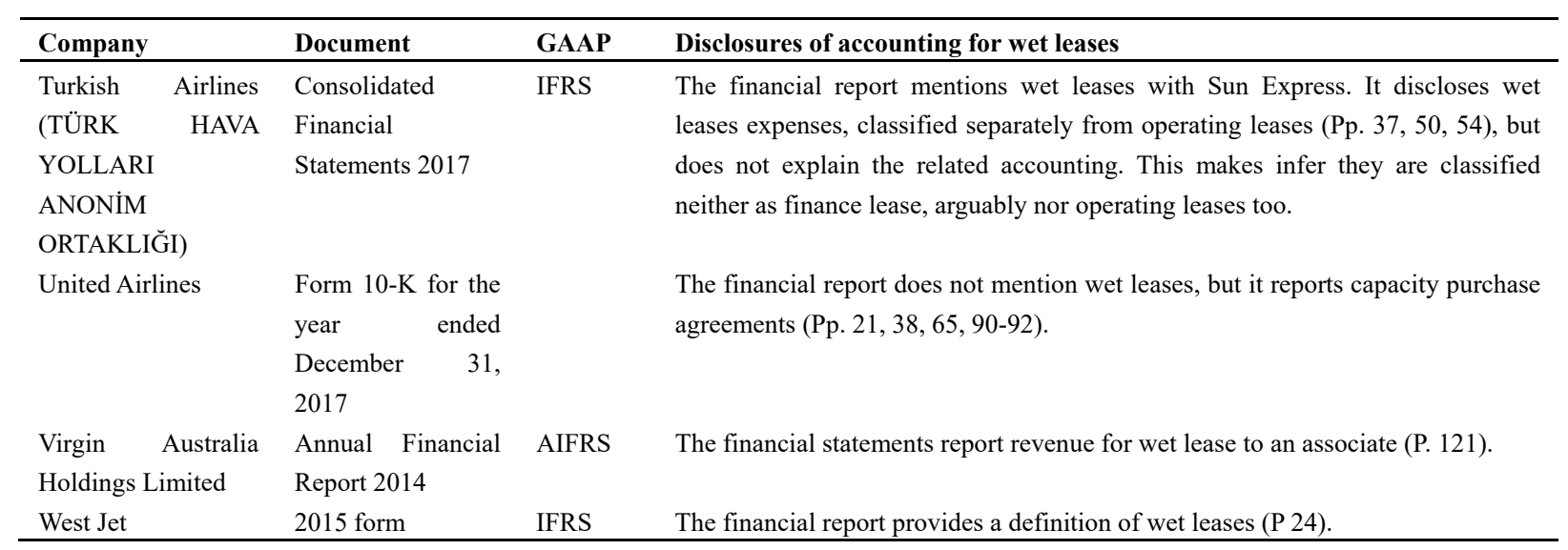

\section{Copyrights}

Copyright for this article is retained by the author(s), with first publication rights granted to the journal.

This is an open-access article distributed under the terms and conditions of the Creative Commons Attribution license (http://creativecommons.org/licenses/by/4.0/). 